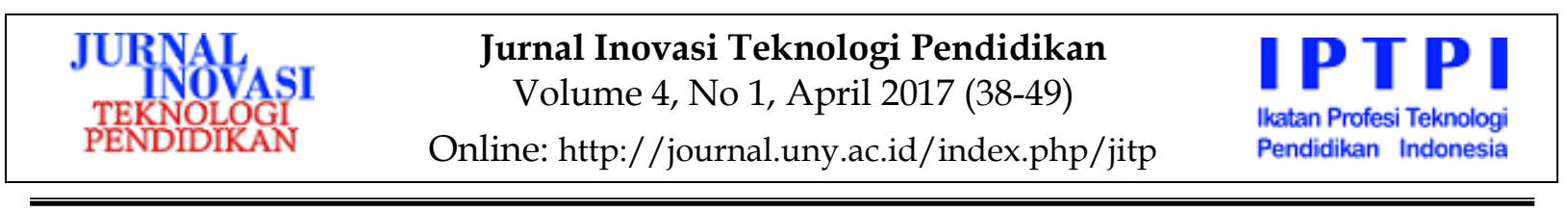

\title{
PENGEMBANGAN MULTIMEDIA PEMBELAJARAN INTERAKTIF BERBENTUK GAME UNTUK MENSTIMULASI ASPEK KOGNITIF DAN BAHASA
}

ANAK TK

\author{
Galih Widyatmojo, Ali Muhtadi \\ Prodi TP PPs UNY, FIP Universitas Negeri Yogyakarta \\ galih.atmaja.9@gmail.com, alimuhtadi1@gmail.com
}

\begin{abstract}
Abstrak
Penelitian ini bertujuan untuk: (1) menghasilkan produk multimedia pembelajaran interaktif berbentuk game, (2) mengetahui kelayakan produk multimedia pembelajaran interaktif, (3) mengetahui kebermanfaatan produk multimedia pembelajaran interaktif berbentuk game untuk menstimulasi aspek kognitif dan bahasa anak TK Kelompok B. Penelitian ini merupakan penilitian dan pengembangan (R\&D) diadaptasi dari model Alessi dan Trollip. Prosedur pengembangan meliputi tahap perencanaan, desain, dan pengembangan. Pada uji alpha dilakukan penilaian oleh 2 ahli materi dan 2 ahli media untuk mengetahui kelayakan produk. Selanjutnya pada uji beta dilakukan terhadap 18 anak kelompok B5 sebagai subjek uji coba di TK Negeri 2 Yogyakarta. Penelitian ini menunjukkan hasil sebagai berikut: (1) produk yang dihasilkan memiliki karakteristik sebagai berikut: game dapat digunakan untuk menstimulasi aspek kognitif dan bahasa yang sesuai dengan kurikulum sekolah, terdiri atas 4 jenis permainan, bersifat portable dan standalone, dapat berjalan dengan komputer spesifikasi rendah. (2) produk yang dihasilkan memenuhi kriteria sangat layak digunakan, (3) produk yang dihasilkan sangat layak digunakan untuk menstimulasi aspek kognitif dan bahasa anak TK Kelompok B ditinjau dari kebermanfaatan. Kata kunci: multimedia pembelajaran interaktif, game, kognitif dan bahasa
\end{abstract}

\section{DEVELOPING INTERACTIVE TEACHING MULTIMEDIA \\ IN THE FORM OF GAMES TO STIMULATE THE COGNITIVE AND LINGUISTIC ASPECTS OF KINDERGARTEN STUDENTS}

\author{
Galih Widyatmojo, Ali Muhtadi \\ Prodi TP PPs UNY, FIP Universitas Negeri Yogyakarta \\ galih.atmaja.9@gmail.com, alimuhtadi1@gmail.com
}

\begin{abstract}
This research study is aimed to: (1) produce interactive teaching multimedia in the form of games kindergarten students, and (2) identify the appropriateness of the developed interactive teaching multimedia. (3) identify the usefulness of the the developed interactive teaching multimedia to stimulate the cognitive and linguistic aspects of group B. This study was a research and development (RED) study adapting Alessi and Trollip's model. The procedures of the study were planning, design, and development. In the alpha test, two materials experts and two media experts examined the product to determine its appropriateness. Then, in the beta test, 18 students of group B5 TK Negeri 2 Yogyakarta participated. The results of the study are as follows (1) The developed interactive teaching multimedia in the form of games have the following characteristics: the games can be used to stimulate the cognitive and linguistic aspects of the students, they match the school curriculum, there are four kinds of game, they are portable and standalone, and they can be operated by computers with low specifications. (2) The developed interactive teaching multimedia in the form of games fulfill the appropriateness criterion so that they are appropriate to be used, (3) the developed interactive teaching multimedia are useful to stimulate the cognitive and lingustic aspects of Group B kindergarten students, viewed from its usefulness.
\end{abstract}

Keywords: interactive teaching multimedia, game, cognitive and linguistic 


\section{Pendahuluan}

Undang-Undang Republik Indonesia Nomor 20 Tahun 2003 tentang Sistem Pendidikan Nasional Pasal 1 ayat 14 menyatakan bahwa Pendidikan Anak Usia Dini (PAUD) adalah suatu upaya pembinaan yang ditujukan kepada anak sejak lahir sampai dengan usia enam tahun yang dilakukan melalui pemberian rangsangan pendidikan untuk membantu pertumbuhan dan perkembangan jasmani dan rohani agar anak memiliki kesiapan dalam memasuki pendidikan lebih lanjut. Pendidikan Anak Usia Dini diselenggarakan melalui jalur formal untuk anak usia 4-6 tahun dalam bentuk Taman Kanak-kanak (TK)/ Raudhatul Atfal (RA) sedangkan untuk usia dibawahnya diselenggarakan melalui jalur non-formal berupa tempat penitipan anak (TPA) dan sejenisnya. (Depdiknas, 2003)

Kementerian Pendidikan dan Kebudayaan melalui Direktorat Pendidikan Anak Usia Dini dan Pendidikan Masyarakat merumuskan tujuan PAUD sebagai berikut: (1) memberikan pengasuhan dan pembimbingan yang memungkinkan anak usia dini tumbuh dan berkembang sesuai dengan usia dan potensinya; (2) mengidentifikasi penyimpangan yang mungkin terjadi, sehingga jika terjadi penyimpangan, dapat dilakukan intervensi dini; (3) menyediakan pengalaman yang beranekaragam dan mengasyikkan bagi anak usia dini, yang memungkinkan dirinya mengembangkan potensi dalam berbagai bidang, sehingga siap untuk mengikuti pendidikan pada jenjang sekolah dasar (SD) (Kemendikbud, 2015).

Taman Kanak-Kanak (TK) merupakan tingkatan pendidikan anak usia dini untuk anak usia 4-6 tahun. Pada masa ini proses belajar ditekankan pada pemberian rangsangan (stimulus) untuk mengembangkan berbagai aspek kemampuan dasar dengan bermain. Bermain pada hakikatnya adalah kegiatan menyenangkan yang dilakukan oleh anak sehari-hari dan merupakan cara anak untuk belajar dari lingkung- an sekitarnya. Bermain memiliki peran penting dalam perkembangan anak pada hampir semua bidang perkembangan, baik perkembangan fisik-motorik, bahasa, intelektual, moral, sosial, maupun emosional (Suyanto, 2005, p. 119).

Aspek yang dikembangkan melalui kegiatan bermain tersebut diantaranya adalah aspek kognitif dan bahasa. Perkembangan kognitif adalah suatu proses berpikir berupa kemampuan untuk menghubungkan, menilai dan mempertimbangkan sesuatu. Dapat juga dimaknai sebagai kemampuan untuk memecahkan masalah atau untuk mencipta karya yang dihargai dalam suatu kebudayaan. Aspek kemampuan bahasa merupakan modal kemampuan berkomunikasi dan berinteraksi dengan orang lain. Pengembangan bahasa diarahkan agar anak mampu menggunakan dan mengekpresikan pemikirannya dengan menggunakan kata-kata (Depdiknas, 2007, p. 3).

Berbeda dengan generasi sebelumnya anak-anak sekarang digolongkan sebagai generasi Digital Native. Menurut Prensky, 2001, p. 1) generasi digital native adalah mereka yang sejak lahir telah dilingkupi oleh berbagai macam peralatan digital seperti komputer, video game, digital music player, kamera video, telepon seluler serta berbagai macam boneka dan perangkat yang khas era digital. Terjadi pergeseran tren bermain bagi anak dari permainan konvensional menuju permainan digital. Belakangan ini banyak sekali permainan yang dapat dimainkan dalam berbagai perangkat mulai dari komputer, Play Station 3, game watch, X-Box, dan smartphone. Berkembangnya permainan di era modern ini memiliki potensi untuk meningkatkan kreatifitas anak. Namun, tidak semua game sesuai dengan tingkat perkembangan anak, banyak game yang beredar mengandung unsur kekerasan, SARA dan unsur lainnya negatif lainnya. Terkadang orangtua membebaskan anak untuk bermain sehingga tidak tahu apa yang dimainkan. Akibatnya anak tidak mendapat manfaat untuk per- 
kembangan pengetahuannya dari permainan tersebut.

Pergeseran tren bermainpun merambah kedalam lingkungan sekolah. Meskipun masih minoritas, namun sedikit demi sedikit TK di Indonesia mulai menyediakan fasilitas komputer untuk membantu proses belajar mengajar dan kebutuhan bermain anak. Beberapa instansi baik dari pemerintah maupun swasta mulai mengembangkan multimedia pembelajaran interaktif, film edukasi dan game edukasi untuk anak. Namun, tidak semua yang dikembangkan sesuai dengan tahapan pencapaian perkembangan anak dalam kurikulum yang diterapkan disekolah. Guru tentunya harus memilah-milah aspek apa yang dapat dikembangkan melalui mediamedia tersebut.

Berdasarkan hasil observasi yang dilaksanakan di TK Negeri 2 Yogyakarta kelompok B5 pada tanggal 10 September 2015 peneliti menemukan beberapa permasalahan. Anak cenderung pasif saat belajar didalam kelas namun aktif ketika bermain menggunakan game komputer. Multimedia pembelajaran dalam komputer tidak menyertakan file audio berupa narasi/ suara pengisi. Anak terlihat bosan dengan multimedia pembelajaran yang digunakan karena kurangnya variasi permainan didalamnya. Hal ini terlihat dari beberapa anak mengganggu teman yang lainnya. Untuk itu diperlukan adanya inovasi baru dengan media lain yang lebih variatif, menarik dan menantang.

Berdasarkan wawancara dengan guru, terdapat masalah dalam perkembangan aspek kognitif dan bahasa. Dalam perkembangan aspek kognitif, banyak anak yang masih tergolong dalam kelompok belum berkembang dalam tingkat capaian memecahkan masalah sederhana dalam kehidupan sehari-hari. Selanjutnya dalam perkembangan aspek bahasa, banyak anak yang belum berkembang dalam tingkat capaian bahasa menyebutkan kelompok gambar yang memiliki huruf/bunyi yang sama, dan memahami hubungan antara huruf dengan bunyi. Multimedia yang digunakan selama ini belum dapat menstimulasi berbagai aspek kemampuan dasar secara maksimal karena materi, indikator, dan tingkat capaian perkembangannya tidak sesuai dengan kurikulum yang diterapkan pada TK Negeri 2 Yogyakarta, multimedia juga digunakan secara berulang kali, dan kurangnya variasi permainan didalamnya.

Sebagai salah satu alternatif dalam pemecahan masalah tersebut adalah mengembangkan multimedia pembelajaran interaktif. Multimedia merupakan gabungan dari dua kata yaitu multi yang berarti banyak dan media diartikan sebagai alat yang digunakan untuk menyampaikan pesan. Mayer (2009, p. 3) mendefinisikan multimedia sebagai presentasi materi dengan menggunakan kata-kata sekaligus gambar-gambar. Vaughan (2011, p. 1) menyatakan bahwa multimedia pembelajaran merupakan kombinasi teks, seni, suara, animasi, dan video yang disampaikan kepada seorang (peserta didik) dengan komputer atau peralatan manipulasi elektronik dan digital yang lain. Melalui gabungan media-media ini pengalaman belajar menjadi sesuatu yang interaktif yang mencerminkan suatu pengalaman dalam kehidupan sehari-hari.

Multimedia pembelajaran dipilih karena memiliki keunggulan yang khas dibandingkan dengan media lainnya. Menurut (Philips, 20013, p. 11) keunggulan tersebut diantaranya adalah: (1) mixed media, mengintegrasikan berbagai media konvensional yang ada kedalam satu jenis media interaktif. Pembelajaran kognitif dan bahasa dalam sekolah tentunya membutuhkan lebih dari satu media baik berupa media visual maupun audio, dengan multimedia media-media tersebut dapat dikemas dalam satu bentuk; (2) user control, memungkinkan pengguna untuk menelusuri materi ajar sesuai dengan kemampuan dan latar belakang pengetahuan yang dimilikinya. Anak dapat mengakses materi yang dibutuhkan dan mengolah informasi secara mandiri, sehingga penyerapan informasi akan lebih efektif. (3) simulation and 
visualization, dengan teknologi animasi, simulasi dan visualisasi pengguna akan mendapatkan informasi yang lebih riil dan informasi yang bersifat abstrak. Bagi anak, informasi yang baru masih berupa sesuatu yang abstrak, untuk itu diperlukan media yang dapat digunakan untuk membantu penyerapan informasi tersebut; (4) different learning styles, multimedia mempunyai potensi untuk mengakomodasi pengguna dengan gaya belajar yang berbeda-beda. Anak memiliki gaya belajar yang berbeda. Anak dengan kecenderungan gaya belajar auditori dapat menyerap informasi apabila menggunakan media audio, visual menggunakan gambar maupun video, kinestetik dengan gerakan. Multimedia dapat menggabungkan media-media yang digunakan tersebut sehingga perbedaan gaya belajar anak dapat teratasi.

Penggunaan multimedia pembelajaran interaktif dalam kelas didukung dengan hasil penelitian yang dilakukan oleh Mayer, McCarthy dan Walton (1993) menyebutkan bahwa multimedia telah memperoleh banyak manfaat yang dari penggunaannya. Keuntungan belajar lebih besar $56 \%$, konsistensi belajar lebih baik 50 $60 \%$ dan retensi konten $25-50 \%$ lebih tinggi (Reddi \& Mishra, 2003, p. 32). Berdasarkan hasil penelitian-penelitian ini, maka multimedia pembelajaran dapat dikatakan sebagai media yang mempunyai potensi yang sangat besar dalam membantu proses pembelajaran.

Multimedia pembelajaran memiliki beberapa bentuk penyajian diantaranya (1) tutorial, (2) hypermedia, (3) drill, (4) simulasi, (5) games, (6) perkakas dan lingkungan belajar open-ended, (7) tes, (8) pembelajaran berbentuk web (Alessi \& Trollip, 2001, p. 10). Merujuk pada hakikat peserta didik yang memiliki kecenderungan belajar sambil bermain maka multimedia pembelajaran disajikan dalam bentuk game. Sebagai solusi dalam permasalahan yang ditemukan di sekolah maka game dikembangkan dengan memperhatikan aspek kognitif dan bahasa sesuai dengan kurikulum dan permasalahan yang ada dalam sekolah. Game kemudian diisi dengan permainan yang variatif, menarik dan menantang.

Penggunaan game memberikan dampak yang positif bagi anak diantaranya (1) membuat anak mengenal teknologi komputer, (2) memberikan pelajaran dalam mengikuti pengarahan dan aturan, (3) menyediakan latihan untuk pemecahan masalah dan logika, (4) menyediakan latihan penggunaan syaraf motorik dan kemampuan spasial. (5) sarana keakraban dan interaksi anak dan orangtua, (6) mengenalkan teknologi dan fiturnya, (7) menyediakan sarana penyembuhan untuk pasien tertentu, (8) menghibur dan menyenangkan (Henry, 2010, p. 53). Berdasarkan hal tersebut, maka multimedia pembelajaran dengan bentuk game sesuai dengan karakteristik peserta didik dan memiliki dampak positif yang beragam bagi anak baik dalam pembelajaran formal maupun hiburan.

Game edukasi merupakan aktivitas terstruktur dimana pemain mengambil keputusan melalui kendali pada objek didalamnya yang digunakan dalam proses pembelajaran. Menurut Chaudhary (2008, p. 9) Game merupakan alat pengajaran yang berguna bagi para pendidik karena memungkinkan mereka untuk menggunakan teknik inovatif untuk memotivasi siswa dan meningkatkan keterampilan belajar mereka. Dalam penerapannya pembelajaran yang nyata terjadi karena siswa secara konstan tertarik dan belajar memecahkan masalah dengan menyelesaikan game. Dengan penjelasan lebih rinci Roslina, Rusimah, Omar, \& Jaffar (2011, p. 207) mendefinisikan game edukasi sebagai game yang mana menggabungkan antara prinsip desain game dan teori belajar dengan mengintegrasikan konten pembelajaran mata pelajaran tertentu untuk memperkaya pembelajaran yang ditujukan kepada siswa. Kramer (2000) menjelaskan di dalam sebuah game selalu memiliki komponen dan peraturan dimana keduanya bisa dikolaborasikan. Game juga memiliki empat unsur, yaitu: (1) peraturan permainan, (2) tujuan yang harus dicapai, (3) kesempatan yang ada dalam permainan, (4) kompetisi. 
Menurut (Alessi \& Trollip, 2001, p. 277) Alessi dan Trollip (2001, p.277) game pada umumnya memiliki tujuh unsur diantaranya (1) tujuan (goals), (2) aturan (rules), (3) kompetisi (competition), (4) tantangan (challenge), (5) fantasi (fantasy), (6) keamanan (safety), (7) hiburan (entertaiment). Adapun unsur-unsur game yang dikembangkan dalam produk game edukasi ini antara lain tujuan, tantangan, kontrol, kompetisi, hukuman, hadiah, fantasi dan hiburan. Selanjutnya teori belajar yang mendasari pengembangan game adalah teori behavioristik, kognitif, dan konstruktivistik.

Alessi \& Trollip (2001, p. 19) menyatakan bahwa teori kognitif berasal dari kata cognition yang bermakna proses mengetahui sesuatu. Teori ini menjadi dasar pengembangan teori belajar yang lain, seperti teori pemrosesan informasi dan teori konstruktivistik. Psikologi kognitif menekankan pada konsep yang tidak teramati, seperti akal, ingatan, sikap, motivasi, pikiran, refleksi, dan proses internal lainnya. Schunk (2012, p. 618) menambahkan bahwa proses kognitif mengaitkan hubungan antara stimulus dan respon sehingga siswa dapat menjaga respon yang sama dalam lingkungan yang berubah atau menunjukan respon yang berbeda di lingkungan yang sama, tergantung apa yang mereka anggap sebagai hal yang adaptif. Jean Piaget (Izzaty, Sugiyanto, Kurniawan, \& Yulianto, 2008, p. 34) mengajarkan bahwa perkembangan kognitif adalah gabungan bagian dari kedewasaan otak dan sistem saraf, serta adaptasi pada lingkungan. Terdapat lima istilah yang digunakan dalam menggambarkan skema perkembangan kognitif yaitu: (1) skema, (2) adaptasi, (3) asimilasi, (4) akomodasi, (5) equlibration.

Menurut Thorndike (Alessi \& Trollip, 2001) tentang teori behaviorisme adalah hal yang menjadi dasar terjadinya belajar adalah adanya asosiasi atau menghubungkan antara kesan indera (stimulus) dengan dorongan yang muncul untuk bertindak (respon) yang disebut dengan connecting. Stimulus yang terjadi setelah sebuah perilaku terjadi akan mempenga- ruhi perilaku selanjutnya. Perubahan tingkah laku akibat dari kegiatan belajar itu yang dapat diamati, yang terjadi karena hubungan stimulus dan respon. Thorndike (Sugihartono, 2007, p. 92) mengemukakan bahwa terjadinya asosiasi antara stimulus dan respon mengikuti hukum-hukum berikut: (1) hukum kesiapan (law of readliness), (2) hukum latihan (law of exercise), (3) hukum akibat (law of effect), yaitu hubungan stimulus dan respon cenderung diperkuat bila akibatnya tidak memuaskan.

(Alessi \& Trollip, 2001, p. 32) menjelaskan, prinsip-prinsip yang disarankan untuk mencapai tujuan pembelajaran berdasarkan teori konstruktivistik ialah: (a) menekankan pembelajaran daripada pengajaran, (b) menekankan siswa untuk berpikir dan bertindak daripada guru, (c) menekankan pembelajaran aktif (active learning), (d) menggunakan pendekatan penemuan atau panduan penemuan, (e) mendorong siswa membangun informasi dan proyek, (f) menggunakan aktivitas cooperative atau collaborative learning, (g) menggunakan aktivitas pembelajaran bermakna, (h) melibatkan siswa untuk memilih dan mengosiasikan tujuan, strategi, dan cara evaluasi pembelajaran, (i) mendorong otonomi pribadi sebagai bagian dari siswa, (j) mendukung refleksi belajar siswa, $(\mathrm{k})$ mendorong siswa untuk menerima dan merefleksikan pada kompleksitas dunia nyata, dan (l) menggunakan penilaian dan aktivitas secara pribadi yang relevan bagi siswa.

Anak usia 5-6 tahun (kelompok B) memiliki target pencapaian perkembangan yang harus dicapai dalam pembelajaran di TK. Untuk mencapai target tersebut dibutuhkan stimulasi terhadap aspek tersebut melalui kegiatan belajar dengan konsep belajar sambil bermain. Dalam penelitian ini multimedia yang dikembangkan ditujukan untuk memberi stimulasi bagi anak dengan aspek kognitif dan bahasa sesuai dengan kurikulum yang diterapkan dan masalah yang terjadi di TK. Multimedia yang dikembangkan diharapkan mampu memberi stimulasi yang unik berupa daya tarik dan motivasi dalam pembelajaran. 
Berdasarkan target tersebut maka indikator penilaian terhadap perkembangan aspek kognitif dan bahasa yang dikembangkan dalam kurikulum Permendiknas No.58 tahun 2009 yaitu: Aspek kognitif, dengan target pencapaian perkembangan memecahkan masalah sederhana dalam kehidupan sehari-hari dengan indikator yang meliputi: (a) mengerjakan maze (mencari jejak) yang lebih kompleks 3-4 jalan, (b) menyusun puzzle menjadi bentuk utuh (lebih dari 8 kepingan), (c) menunjukkan kejanggalan suatu gambar (d) mengambil keputusan secara sederhana. Aspek bahasa, dengan target pencapaian menyebutkan kelompok gambar yang memiliki bunyi/ huruf sama, dengan indikator: menghubungkan gambar/benda dengan kata. Target pencapaian memahami hubungan antara bunyi dan bentuk huruf. Dengan indikator membaca gambar yang memiliki kata/kalimat sederhana.

Penelitian ini dibatasi pada permasalahan belum adanya multimedia pembelajaran yang dapat menstimulasi aspek kognitif dan bahasa yang sesuai dengan tingkat capaian dan indikator dalam kurikulum sekolah. Adapun masalah yang akan diteliti dirumuskan sebagai berikut: (1) bagaimana desain produk multimedia pembelajaran interaktif berbentuk game untuk menstimulasi aspek kognitif dan bahasa anak TK Kelompok B. (2) bagaimana kelayakan produk multimedia pembelajaran interaktif berbentuk game ditinjau dari aspek materi dan media? (3) bagaimana kebermanfaatan produk multimedia pembelajaran interaktif berbentuk game untuk menstimulasi aspek kognitif dan bahasa anak TK Kelompok B?

\section{Metode Penelitian}

Penelitian ini menggunakan model penelitian dan pengembangan atau $R e-$ search and Development (RED) yang mengacu pada model pengembangan Prosedur penelitian dan pengembangan ini mengacu pada model Alessi \& Trolip dengan melalui 3 fase yaitu standard, ongoing evalu- ation, dan project management. Selanjutnya adalah 3 langkah pengembangan yaitu perencanaan (planning), desain (design) dan pengembangan (development).

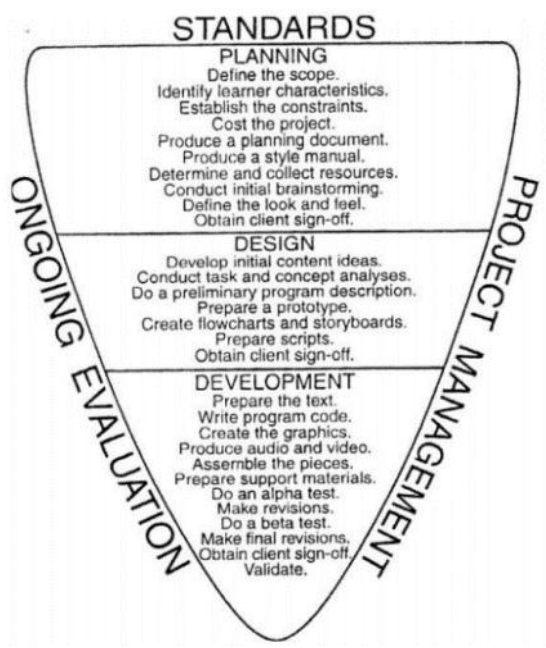

Gambar 1. Model Pengembangan Allesi \& Trollip

Penelitian ini mengunakan pendekatan kuantitatif dengan beberapa data dijabarkan dalam bentuk kualitatif untuk mengetahui kelayakan software yang dihasilkan.

Penelitian ini dilaksanakan pada bulan Agustus 2015 sampai dengan 12 Mei 2016. Penelitian dilakukan di TK Negeri 2 Yogyakarta. Subjek atau responden yang terlibat dalam penelitian ini adalah 2 ahli media, uji ahli media ini untuk menilai dan mengevaluasi produk sebelum diujicobakan pada anak dan 2 ahli materi. Uji ahli materi ini untuk menilai kelayakan materi sebelum diujicobakan pada anak yang mana uji materi dan media termasuk dalam uji alpha. Selanjutnya pada uji beta dilakukan pada 18 anak TK kelompok B.

Dalam pelaksanaannya model pengembangan ini disesuaikan dengan kebutuhan dilapangan dan ruang lingkup dalam pelaksanaan penelitian. 3 fase pengembangan diterapkan sebagai berikut: (a) Standard, meendefinisikan kualitas produk multimedia pembelajaran interaktif berbentuk game yang direncanakan dengan komunikasi antara pengembang, pembimbing dan guru TK Negeri 2 Yogyakarta. 
(b) ongoing evaluation, melakukan evaluasi simultan terhadap produk dari tahap awal hingga akhir pengembangan dengan mengacu pada standar yang telah ditetapkan sebelumnya. (c) projects management, mengatur dan mempertimbangan waktu penelitian, dana sumber daya yang tersedia, termasuk komunikasi antara pihak terkait.

Selanjutnya terkait dengan 3 tahap pengembangan yaitu perencanaan (planning), terdapat 5 langkah yaitu: (1) menetapkan ruang lingkup kajian (define the scope), mendefinisikan tujuan pengembangan $i$, mengatur ruang lingkup materi, menentukan tema yang diangkat, dan menentukan target capaian; (2) mengidentifikasi karakteristik pebelajar (identify learner characteristics), menentuan sasaran pengguna yang akan digunakan sebagai objek penelitian menggunakan game, mengidentifikasi karakteristik siswa dalam hal ini adalah anak Kelompok B5 TK Negeri 2 Yogyakarta; (3) membuat dokumen perencanaan (produce a planning document), mengumpulkan dan membuat dokumen perencanaan pengembangan yang digunakan sebagai bahan diskusi antara pengembang, user, dan pembimbing. Pedoman pengembangan game di TK menyesuaikan dengan masalah pembelajaran dan target capaian yang tercantum dalam Permendiknas No. 58 tahun 2009 tentang Standar Pendidikan Anak Usia Dini; (4) menentukan dan mengumpulkan sumber (determine and collect resource), mengumpulkan dan membuat dokumen perencanaan pengembangan yang digunakan sebagai bahan diskusi antara pengembang, user, dan pembimbing. Pedoman pengembangan game di TK menyesuaikan dengan masalah pembelajaran dan target capaian yang tercantum dalam Permendiknas No. 58 tahun 2009 tentang Standar Pendidikan Anak Usia Dini (5) Melakukan brainstorming (conduct initial brainstorming), Brainstroming merupakan penyatuan pemikiran dalam upaya pemecahan masalah dengan mengumpulkan gagasan. Brainstroming dilakukan dengan pembimbing dan guru kelas B5 TK Negeri 2 Yogyakarta.
Kedua, pada tahap desain, terkait dengan penentuan isi dan menentukan hal-hal yang akan dilakukan dan dalam proses penyampaian pesan instruksional pembelajaran dan perspektif interaktifnya. Pada tahap ini terdapat 2 langkah yaitu: (1) mengembangkan ide (develop initial content ideas), dalam tahap ini semua ide dikembangkan. Ide tersebut terkait penyajian konten, tampilan, gambar, animasi, suara, jenis game, aturan game, dan pemrograman. (2) melakukan analisis konsep dan tugas (conduct task and concept analyses), Analisis tugas dalam hal ini digunakan untuk menentukan tugas yang harus dilakukan dalam pengembangan, sedangkan analisis konsep digunakan untuk mengorganisasikan konsep yang didapatkan dari ide yang sudah dikembangkan sebelumnya (3) membuat deskripsi program awal (do a preliminary program description). tahap ini meliputi penentuan deskripsi awal dari program yang akan dikembangkan. Dalam hal ini dikembangkan Garis Besar Isi Program Media (GBIPM) yang menjadi konsep dasar dalam pengembangan game (4) membuat flowcharts dan storyboards (create flowcharts and storyboard), dalam tahap ini dilakukan pembuatan dokumen perencanaan berupa Flowchart dan Storyboard yang nantinya akan digunakan sebagai panduan pengembangan game dari segi tampilan, layout, tata letak, dan navigasi

Ketiga, yang dilakukan pada tahap pengembangan multimedia adalah menerapkan hasil desain multimedia pembelajaran dalam bentuk produk. Dalam tahap ini terdapat 9 langkah, yaitu: (1) menyiapkan teks (prepare the text), mempersiapkan teks yang disajikan dalam game. dalam penyajian teks dikombinasikan dengan gambar ilustrasi dan suara pendukung. Hal ini dilakukan karena peserta didik belum semuanya dapat membaca (2) menuliskan kode program (write the program code), kode program menggunakan ActionScript 2.0 yang merupakan bahasa pemrograman dalam aplikasi Adobe Flash CS6. Kode digunakan untuk memberi perintah kepada program untuk melakukan sesuatu. Kode 
tersebut merupakan bagian terpenting dalam jalannya game (3) membuat grafik (create the graphic), grafik dikembangkan dalam Adobe Flash CS6, CorelDraw X5, dan Photoshop CS6. Grafik digunakan sebagai visualisasi materi. Grafik pendukung lainnya yang relevan dapat diperoleh dari berbagai sumber di internet (4) memproduksi audio dan video (produce audio and video), audio pendukung dikembangkan menggunakan Adobe Audition, berupa suara pengisi materi, dan narasi. Video dikembangkan dengan Camtasia 8. Video dimanfaatkan untuk pemberian petunjuk bermain dalam game (5) menggabungkan bagian (assemble the pieces), dalam tahap ini unsur teks, grafik, audio dan video digabungkan menjadi satu program berupa game menggunakan Adobe Flash CS6 (6) membuat program (make a program), pada tahap ini bagian yang sudah digabungkan kemudian di ekspor dalam bentuk .swf, selanjutnya game tersebut kemudian dijadikan satu program dengan ekstensi .exe. (7) melakukan uji alfa (do an alpha test), Uji alfa dilakukan oleh ahli materi dan media untuk mengetahui kelayakan program yang dikembangkan. (8) membuat revisi (make revisions), revisi dilakukan untuk melakukan perbaikan program sesuai dengan saran dan komentar validator materi dan media. (9) melakukan uji beta (do a beta test), Uji beta dilakukan pada anak TK kelompok B untuk mengetahui stimulasi aspek kognitif dan bahasa.

Teknik pengumpulan data dalam penelitian ini menggunakan instrumen angket, observasi, dan wawancara. (1) angket, teknik pengumpulan data ini dilakukan dengan cara memberikan angket yang berisi pertanyaan-pertanyaan yang harus dijawab oleh responden. Sifat angket adalah tertutup, dimana responden sudah diberikan pilihan jawaban sehingga responden tinggal memilih jawaban yang sekiranya sesuai dengan keyakinan responden. Teknik pengumpulan data melalui angket dilakukan pada saat uji alpha yang meliputi ahli media dan ahli materi secara langsung. Selanjutnya pada uji beta digu- nakan angket yang diisi oleh observer. (2) observasi, teknik pengumpulan data dengan observasi ini dilakukan dengan cara pengamatan secara langsung kepada subjek penelitian. Teknik observasi memungkinkan peneliti mengetahui lebih mendalam tentang subjek penelitian karena secara langsung mengamati apa yang dilakukan oleh subjek penelitian. Observasi dilakukan saat uji beta untuk mengamati perkembangan aspek kognitif dan bahasa anak saat bermain game. Untuk menghindari bias penelitian maka peneliti dibantu oleh observer lain dan guru. (3) Wawancara, dilakukan untuk mengetahui respon anak terhadap penggunaan game. Hal ini dilakukan pada saat uji beta dan dilakukan oleh observer.

Teknik analisis data dilakukan dengan menggunakan teknik analisis deskriptif kuantitatif yaitu dengan menganalisis data kuantitatif yang diperoleh dari hasil pengujian. Teknik analisis data kelayakan menggunakan skor yang diperoleh dari Skala Likert. Dalam penelitian ini digunakan 4 skala dengan tujuan menghindari jawaban 3, netral atau cukup yang cenderung dipilih oleh pengguna. Tabel kriteria penskoran kelayakan produk dapat dijabarkan sebagai berikut:

Tabel 1. Kriteria Acuan Penskoran

\begin{tabular}{lccl}
\hline No & \multicolumn{1}{c}{ Interval } & Skor & Kategori \\
\hline 1 & $X \geq \bar{X}+1 . S B x$ & 4 & Sangat Layak \\
2 & $\bar{X}+1 . S B x>X \geq \bar{X}$ & 3 & Layak \\
3 & $\bar{X}>X \geq \bar{X}-1 . S B x$ & 2 & Tidak Layak \\
4 & $X<\bar{X}-1 . S B x$ & 1 & Sangat Tidak Layak \\
\hline Sumber: Mardapi (2008, p. 123) & \\
Keterangan Tabel: & \\
$\bar{X} \quad$ : & adalah rerata skor keseluruhan \\
& peserta didik/pengguna dalam satu \\
& kelas. Diperoleh dengan rumus: \\
& $=\frac{1}{2}$ (Skor tertinggi+skor terendah) \\
& $=\frac{1}{2}$ (4+1) = $\frac{1}{2}$ (5) $=2,5$ \\
SBx : & adalah simpangan baku skor \\
& keseluruhan peserta didik daam satu \\
& kelas. Diperoleh dengan rumus
\end{tabular}


$=\frac{1}{6}$ (Skor tertinggi-skor terendah)

$=\frac{1}{6}(4-1)=\frac{1}{6}(3)=0,5$

$X$ : adalah skor yang dicapai oleh peserta didik

Dengan menggunakan kriteria pada Tabel 1, maka didapatkan turunan rumus dalam bentuk skor sebagaimana Tabel 2.

Tabel 2. Kriteria Pemberikan Skor

\begin{tabular}{ccc}
\hline No & Interval & Interpretasi \\
\hline 1 & $4,00 X>3,00$ & SL (Sangat Layak) \\
2 & $2,50<X \leq 3,00$ & L (Layak) \\
3 & $2,00<X \leq 2,50$ & TL(Tidak Layak) \\
4 & $0,01 X \leq 2,00$ & STL (Sangat Tidak Layak) \\
\hline
\end{tabular}

\section{Hasil Penelitian dan Pembahasan}

Penelitian dan pengembangan ini berfokus pada pengembangan produk multimedia pembelajaran interaktif berbentuk game, menguji kelayakan produk berdasarkan penilaian oleh ahli materi dan media, dan uji coba produk untuk menstimulasi aspek kognitif dan bahasa anak TK Kelompok B. Hasil penelitian dan pengembangan ini adalah multimedia pembelajaran berbentuk game untuk menstimulasi aspek kognitif dan bahasa anak TK Kelompok B. Berikut tampilan judul program yang dikembangkan.

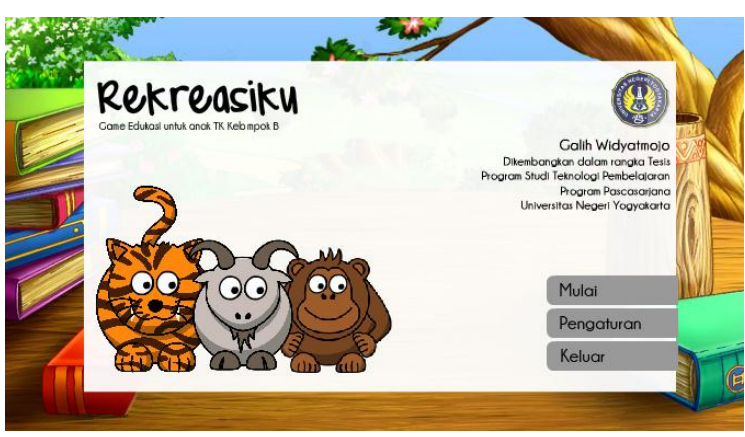

Gambar 2. Halaman Judul Produk

Selanjutnya dilakukan uji coba produk meliputi uji alpha dan uji beta. Uji alpha dilakukan oleh masing-masih 2 ahli media dan 2 ahli materi. Uji beta dilakukan oleh 18 anak TK kelompok B5. Ahli media mengevaluasi multimedia pembelajaran interaktif berbentuk game dari aspek tampilan, navigasi, game pembelajaran, ketahanan produk dan informasi tambahan. Ahli materi mengevaluasi multimedia pembelajaran interaktif berbentuk game dari aspek materi dan pembelajaran. Hasil dari evaluasi media dan materi tersebut dijadikan bahan untuk revisi produk. Setelah dilakukan revisi, selanjutnya dilakukan uji beta untuk memperoleh multimedia pembelajaran interaktif berbentuk game yang dapat menstimulasi aspek kognitif dan bahasa anak TK kelompok B.

Pada uji alpha, dilakukan validasi materi dan media. Validasi materi dilakukan dari tanggal 12 April 2016 hingga 20 April 2016 Validasi dilakukan terhadap materi, rencana kegiatan harian, dan lembar pengamatan. Terdapat 2 aspek yang dinilai oleh ahli materi yaitu aspek materi dan pembelajaran yang dijabarkan kedalam 10 indikator. Hasil penilaian ahli materi 1 terhadap seluruh aspek dan indikator didapatkan rata-rata 3,5 dengan kategori sangat layak. Penilaian ahli materi 2 terhadap seluruh aspek dan indikator didapatkan ratarata 3,7. Sehingga didapatkan rerata total 3,6 dengan kategori sangat layak.

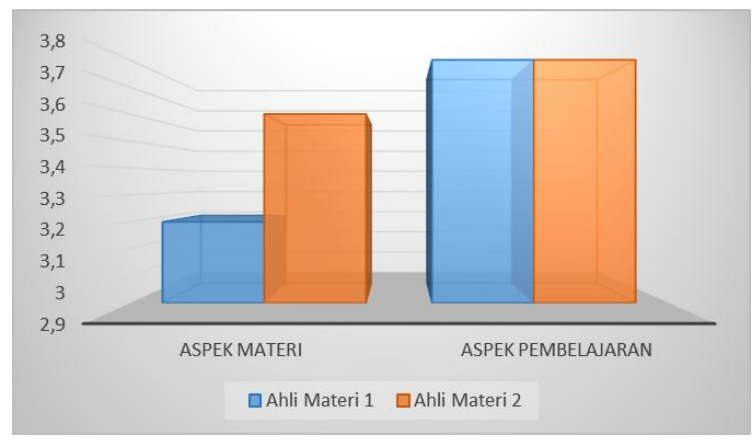

Gambar 3. Diagram Hasil Penilaian Ahli Materi

Hasil penilaian ahli materi 1 terhadap aspek materi didapatkan rerata 3,2 dan aspek pembelajaran 3,8. Penilaian ahli materi 2 terhadap aspek materi didapatkan rerata 3,6 dan aspek pembelajaran 3,8. Sehingga didapatkan rerata total 3,6 dengan kategori sangat layak. 
Selanjutnya penilaian ahli media yang dilakukan dari tanggal 14 April 2016 hingga 20 April 2016. Validasi dilakukan terhadap multimedia pembelajaran berbentuk game. Terdapat 5 aspek yang dinilai oleh ahli media yaitu aspek tampilan, navigasi, game pembelajaran, ketahanan produk, dan informasi tambahan yang dijabarkan kedalam 23 indikator. Hasil penilaian ahli media 1 terhadap seluruh aspek dan indikator didapatkan rata-rata 3,69 dengan kategori sangat layak. Penilaian ahli media 2 terhadap seluruh aspek dan indikator didapatkan rata-rata 3,43. Sehinga didapatkan rerata total 3,56 dengan kategori sangat layak.

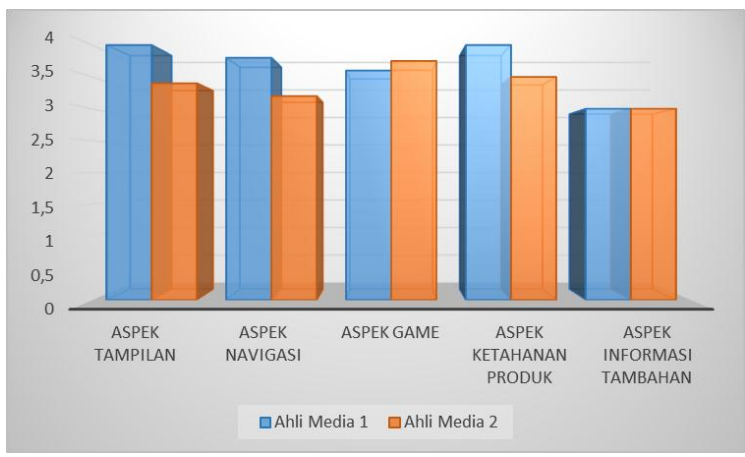

Gambar 4. Diagram Hasil Penilaian Ahli Media

Hasil penilaian ahli media 1 terhadap aspek tampilan dengan rerata 4 , aspek navigasi 3,8, aspek game 3,6 aspek ketahanan produk 4 , dan aspek informasi tambahan 3. Penilaian ahli media 2 terhadap aspek tampilan dengan rerata 3,4, aspek navigasi 3,2, aspek game 3,75 aspek ketahanan produk 3,5, dan aspek informasi tambahan 3.

Uji beta dilakukan secara bertahap sebanyak 2 kali pertemuan dimulai sejak tanggal 28 April 2016 sampai dengan 12 Mei 2016. Peserta didik yang mengikuti proses uji beta berjumlah 18 anak yang berasal dari kelompok B5 TK Negeri 2 Yogyakarta. Uji beta dilakukan didalam laboratorium komputer sekolah dengan fasilitas 1 proyektor dan 15 perangkat komputer. Pada pertemuan pertama peneliti mengenalkan produk kepada anak dan melatih anak kembali dalam mengoperasikan mouse dan keyboard dalam bermain game. Kemudian pada pertemuan kedua dilakukan penilaian oleh observer. Terdapat 2 aspek dalam penilaian terhadap anak yaitu aspek kognitif dengan indikator: (1) mengerjakan maze (mencari jejak) yang lebih kompleks 3-4 jalan, (2) menyusun puzzle menjadi bentuk utuh lebih dari 8 kepingan, (3) menunjukkan kejanggalan suatu gambar dan aspek bahasa dengan indikator: (1) menghubungkan gambar/benda dengan kata, (2) membaca gambar yang memiliki kalimat sederhana. Hasil uji beta kemudian dikonversikan kedalam skala 4 untuk mengetahui tingkat kelayakan.

Tabel 3. Rekapitulasi hasil uji beta

\begin{tabular}{cccc}
\hline Indikator & $\begin{array}{c}\text { Total } \\
\text { Skor }\end{array}$ & $\begin{array}{c}\text { Rerata } \\
\text { Skor }\end{array}$ & Keterangan \\
\hline 1 & 61 & 3,39 & Sangat Layak \\
2 & 68 & 3,78 & Sangat Layak \\
3 & 64 & 3,56 & Sangat Layak \\
4 & 72 & 4 & Sangat Layak \\
5 & 65 & 3,61 & Sangat Layak \\
Jumlah & 330 & 18,33 & \\
Rata-Rata & 66,00 & 3,67 & Sangat Layak \\
\hline
\end{tabular}

Berdasarkan hasil analisis data dan presentase terhadap uji beta tersebut diatas didapatkan nilai rata-rata total 3,67 dengan kategori sangat layak untuk menstimulasi aspek kognitif dan bahasa anak TK kelompok B. Adapun sajian data dalam bentuk diagram pada Gambar 5.

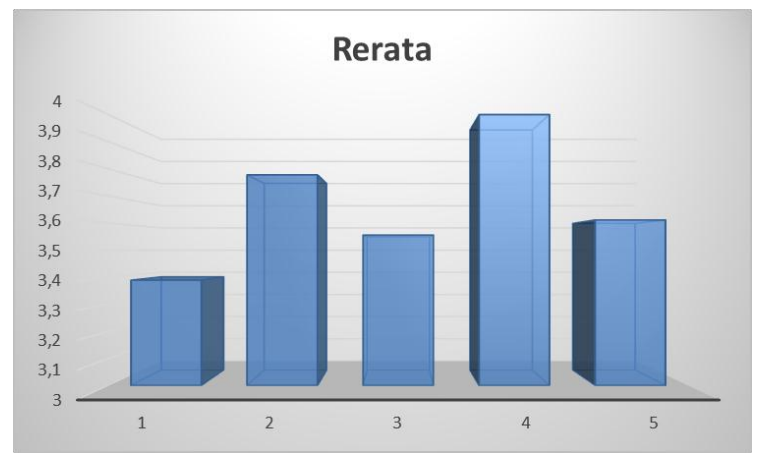

Gambar 5. Hasil uji beta

Multimedia pembelajaran interaktif berbentuk game yang dikembangkan memiliki beberapa keunggulan diantaranya: 
(1) dikembangkan berdasarkan prinsipprinsip multimedia pembelajaran sehingga pesan instruksional yang dimuat didalamnya dapat terserap secara optimal. (2) dikembangkan berdasarkan teori belajar behavioristik, kognitif, dan konstruktivistik sehingga dapat menfasilitasi anak dengan gaya belajar yang berbeda-beda. (3) inovatif dalam pembelajaran karena disajikan dalam bentuk game yang sesuai dengan karakteristik pembelajaran anak TK yaitu belajar dan bermain. (4) dapat di intergrasikan dalam pembelajaran karena disesuaikan dengan tingkat capaian perkembangan anak dalam kurikulum yang diterapkan sekolah. (5) termasuk dalam kategori sangat layak untuk menstimulasi aspek kognitif dan bahasa anak TK Kelompok B dengan hasil penilaian ahli materi dengan rerata 3,6, ahli media 3,56 dan uji beta 3,67. (6). memiliki daya tarik bagi anak dan meningkatkan interaktivitas yang dapat merangsang pembelajaran.

Adapun kelemahan dari multimedia pembelajaran interaktif berbentuk game yang dikembangkan adalah sebagai berikut: (1)game hanya dapat berjalan dalam sistem operasi Windows XP, 7, 8 dan 10 . Belum didukung untuk penggunaan dalam sistem operasi linux dan macintosh. (2) game belum didukung dengan penggunaan dalam perangkat smartphone.

\section{Simpulan dan Saran}

Berdasarkan hasil penelitian dan pengembangan multimedia pembelajaran interaktif berbentuk game dapat disimpulkan sebagai berikut.

Hasil penelitian dan pengembangan berupa produk multimedia pembelajaran berbentuk game dengan karakteristik sebagai berikut: (a) game dikembangkan untuk menstimulasi aspek kognitif dan bahasa anak TK kelompok B sesuai dengan kurikulum yang diterapkan sekolah. (b) game ini terdiri dari 4 jenis permainan diantaranya adalah labirin/maze, puzzle satwa, beda gambar, dan tebak gambar. (c) game ini bersifat portable dan standalone yang berarti tidak memerlukan proses instalasi yang rumit dan tidak membutuhkan program lain untuk dapat berjalan. (d) game ini dapat berjalan dengan lancar walaupun dengan komputer berspesifikasi rendah.

Kelayakan produk multimedia pembelajaran berbentuk game berdasarkan hasil uji alpha dan uji beta adalah sebagai berikut.(a) hasil uji alpha melalui penilaian ahli materi 1 dengan rata-rata skor 3,5 dan ahli materi 2 dengan rata-rata skor 3,7 sehingga didapatkan rata-rata total 3,6 dan termasuk kategori sangat layak. (b) hasil uji alpha melalui penilaian ahli media 1 dengan rata-rata skor 3,69 dan ahli media 2 dengan rata-rata skor 3,43 sehingga didapatkan rata-rata total 3,56 dan termasuk kategori sangat layak.

Kebermanfaatan produk merujuk pada hasil uji beta yang dilakukan terhadap 18 anak TK kelompok B5 TK Negeri 2 Yogyakarta menunjukkan nilai dengan rata-rata skor 3,67 dengan kategori sangat layak digunakan untuk menstimulasi aspek kognitif dan bahasa anak.

Dalam pemanfaatan produk terdapat beberapa hal yang dapat dipersiapkan guru diantaranya adalah: (1) mempersiapkan komputer yang akan digunakan untuk bermain dengan mengcopy game kedalam harddisk maupun menggunakan CD. (2) perlunya melatih anak dalam mengoperasikan komputer terkait dengan penggunaan mouse yaitu klik dan drag and drop, dan penggunaan arah pada keyboard. (3) guru dapat mendampingi anak dalam bermain, terkadang anak kesulitan dalam menyelesaikan permainan apabila tidak memperhatikan petunjuk dengan baik. (4) guru dapat memanfaatkan multimedia pembelajaran yang dihasilkan untuk menstimulasi aspek kognitif dan bahasa anak.

\section{Daftar Pustaka}

Alessi, S. M., \& Trollip, S. P. (2001). Multimedia for learning: methods and development (3rd ed.). Boston: Allyn and Bacon. 
Chaudhary, A. G. (2008). Digital gamebased learning - future of education? Pranjana: The Journal of Management Awareness, 11(2). Retrieved from http://www.indianjournals.com/ijor. aspx?target $=$ ijor:pr\&volume $=11 \&$ issue $=2$ \&article $=001$

Depdiknas. Undang-Undang Nomor 20 Tahun 2003 tentang Sistem Pendidikan Nasional (2003). Jakarta.

Depdiknas. (2007). Pedoman pembelajaran bidang pengembangan berbahasa di taman kanak-kanak. Jakarta: Depdiknas.

Henry, S. (2010). Cerdas dengan game panduan praktis bagi orangtua dalam mendampingi anak bermain game. Jakarta: Gramedia.

Izzaty, R. E., Sugiyanto, Kurniawan, R., \& Yulianto, R. (2008). Perkembangan Peserta didik. Yogyakarta: UNY Press.

Kemendikbud. (2015). Pendidikan anak usia dini. Retrieved August 13, 2015, from http://www.pauddikmas.kemdikbud.go.id/segment/19 .html

Kramer, W. (2000). What is a game? Retrieved February 20, 2016, from http://www.thegamesjournal.com/ar ticles/ WhatIsaGames.html

Mardapi, D. (2008). Teknik penyusunan instrumen tes dan nontes. Yogyakarta: Mitra Cendikia Press.
Mayer, R. E. (2009). Multimedia learning prinsip-prinsip dan aplikasi. (Terjemahan Teguh Wahyu Utomo). (C. U. Press, Ed.). New York.

Philips, R. (20013). The developer's handbook to interactive multimedia (A practical guide for educational applications. New York.: Routledge.

Prensky, M. (2001). Digital natives, digital immigrants part 1 . On the Horizon, 9(5), 1-6.

Reddi, U. V, \& Mishra, S. (2003). Educational multimedia: A handbook for teacher-developers. New Delhi: CEMCA.

Roslina, I., Rusimah, C. M. Y., Omar, H. M., \& Jaffar, A. (2011). Student perception of using educational games to learn introducing programming. Computer and Sciences, 4(1).

Schunk, D. H. (2012). Learning theories an educational perspective. Yogyakarta: Pustaka Pelajar.

Sugihartono. (2007). Psikologi pendidikan. Yogyakarta: UNY Press.

Suyanto, S. (2005). Dasar-dasar pendidikan anak usia dini. Yogyakarta: Hikayat Publishing.

Vaughan, T. (2011). Multimedia: making it works (8th ed.). New York: McGraw Hill. 